Дляцитирования: Юнусова Н.В., Спирина Л.В., Чернышова А.Л., Колегова Е.С., Сиденко Е.А., Коломиец Л.А., Кондакова И.В. Белки клеточной подвижности в карциноме эндометрия и эндометриальной гиперплазии: связь с риском развития рака. Сибирский онкологический журнал. 2020; 19(5): 51-60. - doi: 10.21294/1814-4861-2020-19-5-51-60.

For citation: Yunusova N.V., Spirina L.V., Chernyshova A.L., Kolegova E.S., Sidenko E.A., Kolomiets L.A., Kondakova I.V. Cell motility proteins in endometrium carcinoma and endometrial hyperplasia: association with cancer risk. Siberian Journal of Oncology. 2020; 19(5): 51-60. - doi: 10.21294/1814-4861-2020-19-5-51-60.

\title{
CELL MOTILITY PROTEINS IN ENDOMETRIUM CARCINOMA AND ENDOMETRIAL HYPERPLASIA: ASSOCIATION WITH CANCER RISK
}

\author{
N.V. Yunusova ${ }^{1,2}$, L.V. Spirina ${ }^{1,2}$, A.L. Chernyshova ${ }^{1}$, E.S. Kolegova ${ }^{1}$, \\ E.A. Sidenko', L.A. Kolomiets ${ }^{1,2}$, I.V. Kondakova ${ }^{1}$ \\ Cancer Research Institute, Tomsk National Research Medical Center, Russian Academy of Sciences, \\ Tomsk, Russia ${ }^{1}$ \\ 5, Kooperativny Street, 634050-Tomsk, Russia. E-mail: kondakova@oncology.tomsk.ru¹ \\ Siberian State Medical University, Tomsk, Russia² \\ 2, Moskovsky Trakt, 634050-Tomsk, Russia²
}

\section{Abstract}

Introduction. Proteins associated with cellular motility are known to play an important role in invasion and metastasis of cancer, however there is no evidence of their association with the development of malignant tumors including endometrial cancer (EC). The aim of the present study was to investigate the levels of actin-binding proteins, p45-Ser- $\beta$-catenin, and calpain activity in endometrial hyperplasia and in EC. Material and Methods. Total calpain activity, p45-Ser $\beta$-catenin, Arp3, gelsolin, cofillin and thymosin $\beta-4$ levels were evaluated in 43 postmenopausal patients with stage I-II endometrioid EC and 40 endometrial hyperplasia patients. Flow cytometry and Western blotting were used for expression determination of p45 Ser $\beta$-catenin and actin-biding proteins. Total calpain activity was estimated by fluorimetric method. Results. Levels of cofilin-1, thymosin $\beta-4$ and calpain activity were higher in cancer tissues than in endometrial hyperplasia. Cofilin-1 and thymosin $\beta-4$ levels were associated with the depth of myometrial invasion. The thymosin $\beta-4$ expression was correlated with the presence of tumor cervical invasion. Revealed correlations between the actin-binding proteins, p45-Ser- $\beta$-catenin and total calpain activity in endometrial hyperplasia tissue, but not in the tissue of cancer, is evidence of the involvement of these proteases in regulation of cell migration in endometrial hyperplasia. Levels of thymosin $\beta-4$, cofilin and total calpain activity are independent cancer risk factors in patients with endometrial hyperplasia. Conclusion. The level of actin-binding proteins as well as the total calpain activity were enhanced in endometrium carcinoma tissues compared to endometrial hyperplasia. The levels of thymosin $\beta-4$, cofilin and total calpain activity in endometrial hyperplasia tissues are associated with a hyperplasia transition to cancer and may be considered as predictive biomarkers.

Key words: endometrial hyperplasia, endometrium carcinoma, invasion, actin- binding proteins, p45-Ser- $\beta$-catenin, total calpain activity. 


\title{
БЕЛКИ КЛЕТОЧНОЙ ПОДВИЖНОСТИ В КАРЦИНОМЕ ЭНДОМЕТРИЯ И ЭНДОМЕТРИАЛЬНОЙ ГИПЕРПЛАЗИИ: СВЯЗЬ С РИСКОМ РАЗВИТИЯ РАКА
}

\author{
Н.В. Юнусова ${ }^{1,2}$, Л.В. Спирина ${ }^{1,2}$, А.Л. Чернышова', Е.С. Колегова', \\ Е.А. Сиденко ${ }^{1}$, Л.А. Коломиец ${ }^{1,2}$, И.В. Кондакова ${ }^{1}$
}

\begin{abstract}
Научно-исследовательский институт онкологии, Томский национальный исследовательский медицинский центр Российской академии наук, г. Томск, Россия ${ }^{1}$

Россия, 634009, г. Томск, пер. Кооперативный, 5. E-mail: kondakova@oncology.tomsk.ru1

ФГБОУ ВО «Сибирский государственный медицинский университет» Минздрава РФ,

г. Томск, Россия²

Россия, 634050, г. Томск, Московский тракт, $2^{2}$
\end{abstract}

\section{Аннотация}

Введение. Известно, что белки, связанные с клеточной подвижностью, играют важную роль в инвазии и метастазировании злокачественных опухолей, тем не менее нет данных об их связи с развитием новообразований, в том числе рака эндометрия (РЭ). Целью исследования было изучение уровня актин-связывающих белков, p45-Ser-ß-катенина и активности кальпаинов при гиперплазии эндометрия и при РЭ. Материал и методы. Общая активность кальпаинов, уровни p45-Ser $\beta$-катенина, Arp3, гельзолина, кофиллина и тимозина $\beta-4$ были оценены у 43 больных раком эндометрия I-II стадии в постменопаузе и у 40 пациенток с гиперплазией эндометрия. Проточную цитометрию и вестерн-блоттинг использовали для определения экспрессии p45 Ser $\beta$-катенина и актин-связывающих белков. Общая активность кальпаинов оценивалась фрлуориметрическим методом. Результаты. Уровни кофилина-1, тимозина $\beta-4$ и активность кальпаинов были выше в тканях злокачественных опухолей, чем при гиперплазии эндометрия. Уровни кофилина-1 и тимозина $\beta-4$ были связаны с глубиной инвазии рака эндометрия в миометрий. Содержание тимозина $\beta-4$ коррелировало с наличием инвазии опухоли в шейку матки. Выявленные корреляции между актин-связывающими белками, p45-Ser-ß-катенином и общей активностью кальпаинов в ткани гиперплазии эндометрия, но не в ткани рака свидетельствуют об участии этих протеаз в регуляции клеточной миграции при гиперплазии эндометрия. Уровни тимозина-4, кофилина и общая активность кальпаинов являются независимыми факторами риска развития рака у пациентов с гиперплазией эндометрия. Заключение. Уровень актин-связывающих белков, а также общая активность кальпаинов были повышены в тканях карциномы эндометрия по сравнению с гиперплазией эндометрия. Уровни тимозина-4, кофилина и общая активность кальпаинов в тканях гиперплазии эндометрия могут быть независимыми факторами риска развития рака.

Ключевые слова: гиперплазия эндометрия, карцинома эндометрия, инвазия, актин-связывающие белки, p45-Ser- $\beta$-катенин, общая активность кальпаинов.

\section{Introduction}

Endometrium carcinomas (EC) are the most common gynecological malignancy worldwide, which are connected with considerable mortality [1]. The endometrioid adenocarcinoma is the most frequent histological variant, accounting for about $80 \%$ of the disease cases. Risk factors for EC include age, obesity, menstrual, reproductive and lifestyle factors [2]. Hormonal and metabolic mechanisms are particularly strongly implicated in the pathogenesis of endometrioid adenocarcinoma [2-4]. This subtype is often preceded by precursor lesions, atypical endometrial hyperplasia [5]. Complex hyperplasia and atypical hyperplasia, in particular, are more likely progressed to cancer and therefore are commonly treated with a progestin or hysterectomy [6].

Among the factors that may influence the inception and course of EC estrogens, components of signaling pathways, proteases, growth and transcriptional factors have been most intensively studied [7-10]. However, molecular mechanisms involved in EC development are not fully understood. Neoplastic cancer transformation and following cancer progression are associated with the basic cancer properties as disorders of the cell adhesion and locomotion. The acquirement of the malignant phenotype leads to changes in cell cytoskeleton, wich are important for epithelial cancer cell proliferation, migration and epithelialmesenchymal transition [11]. The remodeling of actin cytoskeleton plays a central role in generating force to drive cell locomotion, and the cytoskeleton remodeling is regulated by a plethora of actin- binding proteins (ABPs). These ABPs perform the following functions: bind actin monomers and prevent its polymerization (e.g., thymosin $\beta-4$ ); depolymerize filaments (e.g., cofilin-1); sever actin filaments by binding to the side of F-actin and cutting it into two pieces (e.g., gelsolin); facilitate the formation of filament 
bundles, branching filaments, and three-dimensional networks (e.g., Arp2/3, fascin) [12]. Thymosin $\beta-4$ hyperexpression leads to the loss of E-cadherin and occludin expressions, increased fibronectin level, $\beta$-catenin rearrangement to cytosol and stimulation of cell migration activity and invasion ability in vitro [13]. Overexpression of cofilin 1 was found in cancer of the bladder and breast [14]. Increased motility of colonic cancer cells was accompanied by a reduction of $\beta$-catenin and up-regulation of gelsolin [15]. Arp2/3mediated actin cytoskeletal rearrangement resulted in breast cancer invasion and metastasis [16].

Expression of the major ABPs involved in actin reorganization has not been extensively studied in endometrial hyperplasia and in EC. Differentiation induction of human endometrial adenocarcinoma cells was associated with a dramatic actin filament reorganization and relocalization of gelsolin from the plasma membrane to the cytoplasm [17]. Induction of cortical actin polymerization in endometrial carcinoma led to conformational change of the ARP $2 / 3$ protein, increased membrane E-cadherin, $\beta$-catenin and promoted epithelial integrity [18].

Cell motility is regulated by $\mathrm{Wnt} / \beta$-catenin pathway required for the endometrial neoplasia formation [19]. In tissues $\beta$-catenin plays a dual role. Inside cell it is mostly located in association with the plasma membrane as a component of the adherent junctions with cadherins providing cell-cell adhesion and reducing cell motility. Another pool of $\beta$-catenin, free from cadherin, is an essential component of $\mathrm{Wnt} / \beta$-catenin signaling pathway; in presence of Wnt signal, increased levels of cytoplasmic $\beta$-catenin accumulate and enter the nucleus where it interacts with the TCF/LEF family of DNA-binding proteins that change transcription of target genes implicated in cell proliferation, adhesion and migration. This transcriptionally active $\beta$-catenin is usually phosphorylated at Ser45, so noncanonical Wnt signaling is associated with $\mathrm{p} 45$-Ser- $\beta$-catenin accumulation in cytoplasm and its translocation into the nucleus [19]. Probably, p45-Ser- $\beta$-catenin may regulate the expression of ABPs, but additional confirmation is required for this hypothesis.

Cancer cell movement is linked to calciumdependent intracellular nonlysosomal cysteine proteases calpains which affect cancer progression through many pathways, such as epithelial-mesenchymal transition, $\mathrm{Wnt} / \beta$-catenin ( $\beta$-catenin) and the nuclear factor $\kappa \mathrm{B}(\mathrm{NF}-\kappa \mathrm{B})$ signaling pathways [20]. The calpains are essential in many cellular processes including apoptosis, proliferation and are involved in cell migratory process and cytoskeletal reorganization through cleavage of specific substrates and providing invadopodia turnover [21]. Recent evidence indicates that the metastasis of stomach, colorectal and ovarian cancer is associated with the activity of calpains in the tissues of the primary tumors [22-24]. Activity of calpain are not well known in EC and endometrial hyperplasia, but immunhistochemical analysis showed a higher expression of calpain endogenous specific inhibitor calpastatin in EC than in benign endometrial tissue [25].

So, although an important role of motilityassociated proteins in cancer is well documented, but there are still no data on connection between the p45-Ser $\beta$-catenin, ABP levels and calpain activity in endometrial hyperplasia and EC. Therefore, the aim of our study was to compare expression of $\mathrm{p} 45-\mathrm{Ser}$ $\beta$-catenin, actin-binding proteins (Arp3, gelsolin, cofilin- 1 and thymosin $\beta-4$ ) and calpain activity in EC and endometrial hyperplasia to identify new cancer risk factors.

\section{Materials and methods}

Patients. The study included 43 postmenopausal patients with stage I-II endometrioid EC (mean age $56.8 \pm 1.5$ years) and 40 patients with complex typical and atypical endometrial hyperplasia (mean age 51.8 \pm 2.8 years). All patients were treated at the Cancer Research Institute, Tomsk National Research Medical Center of the Russian Academy of Sciences (Tomsk, Russian Federation) from January 2014 to January 2016. The study was approved by the Local Committee for Medical Ethics. All patients provided written informed consent. All EC patients underwent total hysterectomy and bilateral salpingo-oophorectomy with or without pelvic lymphadenectomy. In accordance with FIGO classification (2009), Stage Ia $(<1 / 2$ myometrial invasion) and Stage $\mathrm{Ib}(>1 / 2$ myometrial invasion) were identified. However, we divided patients into 3 groups with respect to invasion depth. Patients with Stage Ia were subdivided into 2 groups: without myometrial invasion (tumor affected only the endometrium) and with superficial myometrioal invasion (less than $1 / 2$ myometrial invasion). Moreover, presence of the cervical invasion was evaluated. Endometrial hyperplasia patients underwent either endometrial ablation or subtotal hysterectomy. Endometrial tumor and hyperplasia tissues were collected during surgery. The distance for samples of non-transformed surrounding tissue to be taken was at least $2 \mathrm{~cm}$ from the visible tumor border. All specimens were clinicopathologically reviewed.

Preparing cell suspension. Samples of endometrial tissues were disintegrated on Becton Dickinson (BD) Medimashine System using BD "Cell Wash" buffer. Cell suspension was filtrated through a $50 \mu \mathrm{m}$ Syringe Filcons nylon filter. This procedure is optimal for cell suspensions from tissues due to the absence of their contamination. The improvement of cell suspensions production, decreased level of cytopasmatic membrane proteins impairment (damage, injury) are also referred to as this procedure's main benefits. Number of cells was counted in BD Trucount tubes (BD, USA) by flow cytometry.

Flow cytometry. For intracellular staining cells were fixed and permeabilized using Cytofix/Cytoperm kit (BD, USA) (standard protocol). Aliquots of cell 
suspensions were incubated with conjugated or unconjugated primary antibodies at $20^{\circ} \mathrm{C}$ for 30 minutes, washed, and then stained with the secondary antibodies for 30 minutes. As primary antibodies we used anti-p45 Ser $\beta$-catenin phycoerythrin (PE), anticytokeratin 18 fluorescein isothiocyanate (FITC), anti-cytokeratin 18 PE (BD, Santa Cruze), anti-Arp3 (Abcam), anti-gelsolin (BD). Secondary antibody was goat anti-mouse IgG FITC (BD). Results were analyzed using FACS Diva 6.1. Software. Percentage of cells specifically stained for $\mathrm{p} 45$-Ser-beta-catenin, Arp3 and gelsolin was analyzed (\%).

Preparing tissue homogenates. All procedures were performed at $4{ }^{\circ} \mathrm{C}$. Frozen samples of tumor and adjacent tissues were homogenized and then resuspended in $50 \mathrm{mM}$ Tris- $\mathrm{HCl}(\mathrm{pH} 7.5), 100 \mathrm{mM}$ $\mathrm{NaCl}, 1 \mathrm{mM}$ EDTA, $1 \mathrm{mM}$ dithiothreitol, $10 \%$ glycerol, $10 \mathrm{mM} \mathrm{Na} \mathrm{S}_{2} \mathrm{O}_{5}$ in the ratio 1:6 (w:v). Homogenates were centrifuged at $10,000 \mathrm{~g}$ for 30 min. Protein concentration in cleared homogenates was determined by the method of Lowry.

Electrophoresis. SDS-PAGE was used, according to the method of Laemmli. The samples were incubated

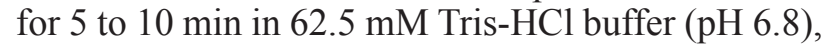
containing $2.0 \%(\mathrm{w} / \mathrm{v}) \mathrm{SDS}, 5.0 \%(\mathrm{v} / \mathrm{v}) / 3-$ mercaptoethanol, $10 \%$ (v/v) glycerol, and $0.0012 \%$ Bromophenol blue.

Western Blot Analysis. After SDS-PAGE, the gels were equilibrated for $10 \mathrm{~min}$ in $25 \mathrm{mM}$ Tris and $192 \mathrm{mM}$ glycine in $20 \%(\mathrm{v} / \mathrm{v})$ methanol. The proteins were transferred to $0.2-/ \mathrm{xm}$ pore-sized PVDF membrane (GE Healthcare, UK), either at $150 \mathrm{~mA}$ or $100 \mathrm{~V}$ for $1 \mathrm{~h}$ using Bio-Rad Mini TransBlot electrophoresis cell according to the method described in the manual accompanying the unit. The PVDF membrane was incubated in a 1:500 dilution of monoclonal mouse human anti-cofilin and in a 1:1000 dilution anti-TIMSB4Y (Abcam, UK) overnight at $4{ }^{\circ} \mathrm{C}$, followed by three consecutive washes in $10 \mathrm{mM}$ Tris- $\mathrm{HCl}$ buffer ( $\mathrm{pH}=7.5$ ), containing $150 \mathrm{mM} \mathrm{NaCl}$ (10 $\mathrm{min} / \mathrm{wash})$. The PVDF membrane was incubated in a 1:10000 dilution of anti-mouse antibodies for 1 h. After three more 10-min washes, the nitrocellulose samples were incubated in Amersham ECL western blotting detection analysis system according to the method described in the manual accompanying the unit and then were exposed to ECL-films (Amersham, USA). The image analysis was performed using "ImageJ" software. Results were standardized for beta-actin levels. The level of peptides in cancer tissues was expressed in percentages to their level in non-transformed tissues, with the expression of studied proteins indicated as $100 \%$. The level of peptides in hyperplastic tissues was expressed in percentages to their expression in cancer ones.

Calpains activity assay. The calpains activity was performed in tissue homogenates using the fluorogenic substrate N-Succinyl-Leu-Leu-Val-Tyr-7-Amido-4Methylcoumarin (Suc-LLVY-AMC) in a Hitachi-850
(Japan) fluorimeter at an excitation wavelength of $380 \mathrm{~nm}$ and an emission of $440 \mathrm{~nm}$ (26). The calpains activity solution contained $100 \mathrm{mM}$ Tris- $\mathrm{HCl}$ $(\mathrm{pH}=7.3), 145 \mathrm{mM} \mathrm{NaCl}$ and $301 \mathrm{M}$ Suc-LLVYAMC. Incubations were performed at room temperature for $30 \mathrm{~min}$ in absence or presence of $10 \mathrm{mM} \mathrm{CaCl} 2$ and N-Acetyl-L-leucyl-L-leucyl-L-norleucinal (calpain inhibitor I). The reaction was stopped by the addition of $1 \%$ sodium dodecyl sulfate. Calpains activity was measured as fluorogenic units per mg protein. Protein concentration was determined by Lowry.

Statistical analysis. Statistical analysis was performed using Statistica 10.0 software. All data are expressed as median with interquartile ranges. To evaluate the difference either Mann-Whitney or Kruskal-Wallis test was applied. Correlation analysis on data was carried out with Spearman Rank Correlation test. The level of significance was set at $p<0.05$. Logistic regression analysis was used to determine the contribution of variables to the variation of observed dependent variables. The data consist of Odd's ratio given by a regression function $f(x, \beta)$, their $95 \%$ confidence interval and p-level.

\section{Results and discussion}

We first examined the ABP levels in EC and endometrial hyperplasia. The data on $\mathrm{p} 45$-Ser $\beta$-catenin, Arp3 and gelsolin levels in endometrial hyperplasia and cancer tissues are shown in Fig. 1. Cofilin- 1 and thymosin $\beta-4$ level in hyperplastic and malignant endometrium are presented in Fig. 2. The percentage of keratin-18-positive cells stained antiArp3+FITC antibodies was decreased in cancer tissues compared with endometrial hyperplasia ( $43.4 \%$ and $50 \%$, respectively, $\mathrm{p}=0.023$ ). The levels of cofilin- 1 and thymosin $\beta-4$ were $40 \%$ lower in tissue hyperplasia compared with tumor $(\mathrm{p}=0.02)$.

The previously findings have been described that cofilin-1 expression increased gradually in normal ovarian tissues, benign tumors, borderline tumors and carcinomas, respectively [27]. The high level of cofilin-1 in EC in comparison to hyperplastic tissues observed in our investigation is consistent with these data. Research of B.D. Gun et al. (2012) has revealed the increased fascin level in proliferative endometrium in comparison to EC [28]. Arp3 and fascin take part in formation of bundles and lamelipodia. We have also shown the high level of protein Arp3 in hyperplasia in comparison to EC tissues. Probably, decreased levels of cofilin-1, thymosin $\beta-4$ and increased expression of Arp3 in endometrial hyperplasia are necessary for cytoskeleton reconstruction, which gives mechanical support to cells and for some extent of cell during proliferation.

Migration is important process of tumor cell invasion and is accompanied by actin cytoskeleton rearrangement by ABPs. Molecular mechanisms of formation of invasive protrusions in transformed cells, such as lamellipodia and invadopodia, is associated 


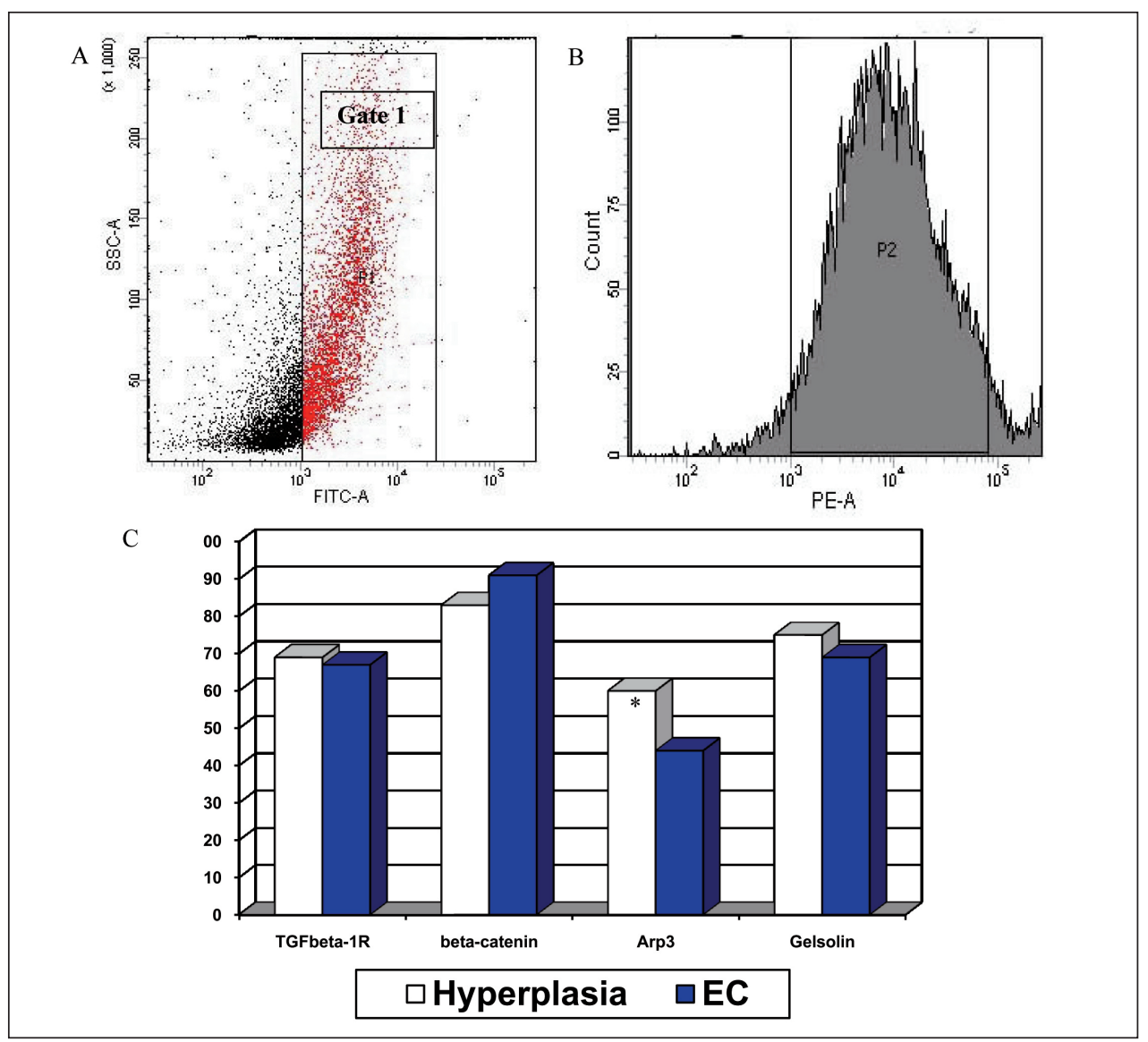

Рис. 1. Высокая экспрессия of p45 Ser $\beta$-катенина в ткани РЭ (проточная цитофлуориметрия):

A - цитокератин-18-позитивные клетки (Gate 1); B - гистограмма, отражающая интенсивность флюоресценции и процент (\%) цитокератин-18-позитивных клеток, окрашенных антителами к гельзолину;

C - процент цитокератин-18-позитивных клеток, окрашенных anti-Arp3+FITC и anti-gelsolin+FITC aнтителами.

Примечание: * - значимость различий по сравнению с тканью рака, $p=0,023$

Fig. 1. High expression of p45 Ser $\beta$-catenin in EC tissue (flow cytometry):

A - keratin-18-positive cells (Gate 1); B - Histogram reflecting fluorescence intensity and percentage (\%) of keratin-18-positive cells stained anti-gelsolin antibody; C - Percentage of keratin-18-positive cells stained anti-Arp3+FITC and anti-gelsolin+FITC antibodies. Note: * - the difference was significant compared to cancer tissues, $p=0,023$

with the functions of key regulatory proteins of the actin cytoskeleton. Therefore we analyzed the expression of ABPs in cancer samples in relation to tumor invasion.

Our data on $\mathrm{p} 45-$-Ser- $\beta$-catenin, Arp3, gelsolin, cofilin- 1 and thymosin- $\beta 4$ expression in relation to myometrial and cervical invasion in EC patients are presented in Table 1. Levels of cofilin-1 and thymosin $\beta-4$ were increased in tumors with deep invasion in the myometrium compared with tumors without invasion ( $p=0.03$ and 0.04 , respectively). The levels of cofilin- 1 in EC patients without myometrial invasion and with superficial invasion were the same, while its level in patients with deep myometrial invasion was $48 \%$ higher than in patients with superficial invasion. These findings indicate that cofilin-1 participates in EC progression. It was revealed that cofilin 1 overexpression can predict progression-free survival in serous ovarian cancer patients receiving the standard therapy [29].

The level of thymosin $\beta-4$ was more than 3.0-fold higher in tumor tissues of patients with superficial and deep myometrial invasion than in patients without myometrial invasion $(p<0.05)$. The thymosin $\beta-4$ level was also varied depending on the presence or absence of tumor cervical invasion. Higher levels of these proteins were detected in EC patients with cervical invasion (33 and $95 \%$, respectively). Solid tumors, including colorectal cancer, were reported to exhibit overexpression of thymosin $\beta-4$ associated with malignant progression [30].

Gelsolin level, having the similar functions in cell in EC tissues, was not associated with any variants of the EC invasion. The role of gelsolin in tumor growth and progression is likely to be contradictory. For example, gelsolin level in cervical cancer tissue was higher than in adjacent normal tissue and further increased in more advanced cases. On the other hand, gelsolin level was decreased in cancer cell line and human ovarian cancer tissues compared to adjacent tissues [31].

In our study, relation between Arp3 expression and EC myometrial and cervical invasion was not 


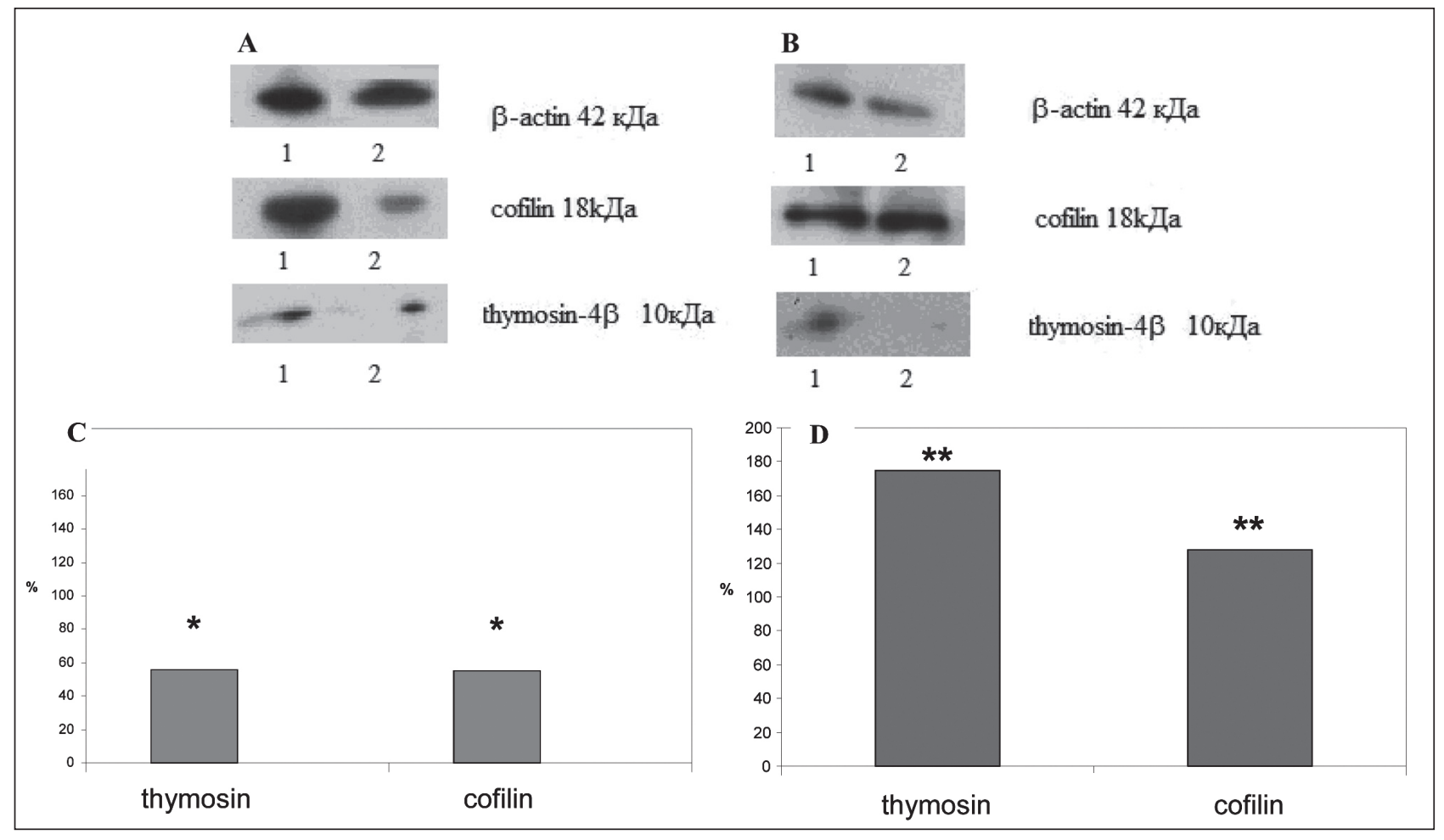

Рис. 2. Экспрессия кофилина и тимозина 4 beta в гиперплазированном, нетрансформированном и малигнизированном эндометрии: А - вестерн блоты кофилина-1 и тимозина beta-4 в гиперплазированном и малигнизированном эндометрии; В - вестерн блоты кофилина-1 и тимозина beta-4 в ткани нетрансформированного и малигнизированного эндометрия;

C - кофилин-1 и тимозин beta-4 в гиперплазированном эндометрии в процентах от экспрессии белка в образцах РЭ (в сравнении с трансформированной тканью); D - кофилин-1 и тимозин beta-4 в ткани рака по отношению к экспрессии белка в нетрансформированном эндометрии (в сравнении с нетрансформированной тканью).

Примечание: A: 1 - экспрессия кофилина-1 и тимозина бета-4 в раковых тканях, 2 - при гиперплазии; В: 1 - экспрессия кофилина-1 и тимозина бета-4 в раковых тканях, 2 - в нетрансформированных тканях. * - различия по сравнению с трансформированной тканью $p=0,02 ;{ }^{* *}$ - различия по сравнению с нетрансформированной тканью, $p=0,01$

Результаты стандартизировали с использованием экспрессии-актина в образце и выражали в процентах от содержания белка в малигнизированных и нетранссормированных тканях

Fig. 2. Cofilin-1 and thymosin beta-4 expression in hyperplastic, non-transformed and endometrial cancer tissues: A - western blots of cofilin-1 and thymosin beta-4 in hyperplastic and endometrial cancer tissues; B - western blots of cofilin-1 and thymosin beta-4 in nontransformed and endometrial cancer tissues; C - cofilin-1 and thymosin beta-4 in hyperplastic tissues in percentages to their expression

in cancer ones (in comparison with transformed tissue); D - cofilin-1 and thymosin beta-4 in cancer tissues in percentages to their expression in non-transformed ones (in comparison with non-transformed tissue).

Note: A: 1 - cofilin-1 and thymosin beta-4 expression in cancer tissues, 2 - in hyperplasia; B: 1 - cofilin-1 and thymosin beta-4 expression in cancer tissues, 2 - in non-transformed tissues. * - in comparison with transformed tissue, $p=0.02$; ${ }^{* *}-$ in comparison with non-transformed tissue, $p=0.01$.

The results were standardized using the $\beta$-actin expression in a sample and were expressed in percentages to protein content in cancer and non-transformed tissues

detected. However, it was shown in gastric carcinomas, Arp2 and Arp3 expression levels were correlated with tumor size, stage, invasion depth and vascular tumor emboli [32]. It was shown that Arp 2/3 took part in the organization of lamellipodial structure, and inhibition of its function reduces the migration of the migration of cancer cells in vitro [33].

The study of the level of $\mathrm{p} 45$-Ser- $\beta$-catenin, which is important component of intracellular signal transduction connected with cell motility, showed no relationship between $\mathrm{p} 45$-Ser- $\beta$-catenin expression and myometrial and cervical invasion of EC.

The results on the total activity of calpains in hyperplastic and malignant tissues of endometrium are presented in Table 2. The activity of calpains in the EC tissue was 7.4 times higher than for endometrial hyper- plasia $(\mathrm{p}=0.000)$. Some previous studies have explored the role of calpains in intercellular adhesion, alteration of the actin cytoskeleton, morphological transformation, cell migration and cancer progression [20-22]. The activity of calpains in EC varied depending on the depth of tumor invasion in the myometrium and was the largest at deep invasion compared with endometrial cancer without invasion $(127.8(85.8-159.8) \times 1.000$ $\mathrm{ME} /$ per mg protein and $54.0(49.0-59.0) \times 1.000 \mathrm{ME} /$ per mg protein, $\mathrm{p}=0.03$ ) (Table 3 ).

In endometrial hyperplasia correlation analysis revealed positive relationship between total calpain activity and gelsolin $(\mathrm{R}=0.929, \mathrm{p}=0.003)$ and Arp3 $(\mathrm{R}=0.929, \mathrm{p}=0.003)$. These relationships can be explained by the common regulatory mechanisms involved in reorganization of the cytoskeleton in 


\section{Уровень p45 Ser $\beta$-катенина. Arp3. гельзолина. кофилина-1 и тимозина $\beta 4$ в образцах рака} эндометрия в зависимости от глубины миометриальной и цервикальной инвазии

The level of $p 45$ Ser $\beta$-catenin. Arp3. gelsolin. cofilin-1 and thymosin $\beta 4$ in EC samples dependent on myometrial and cervical invasion.

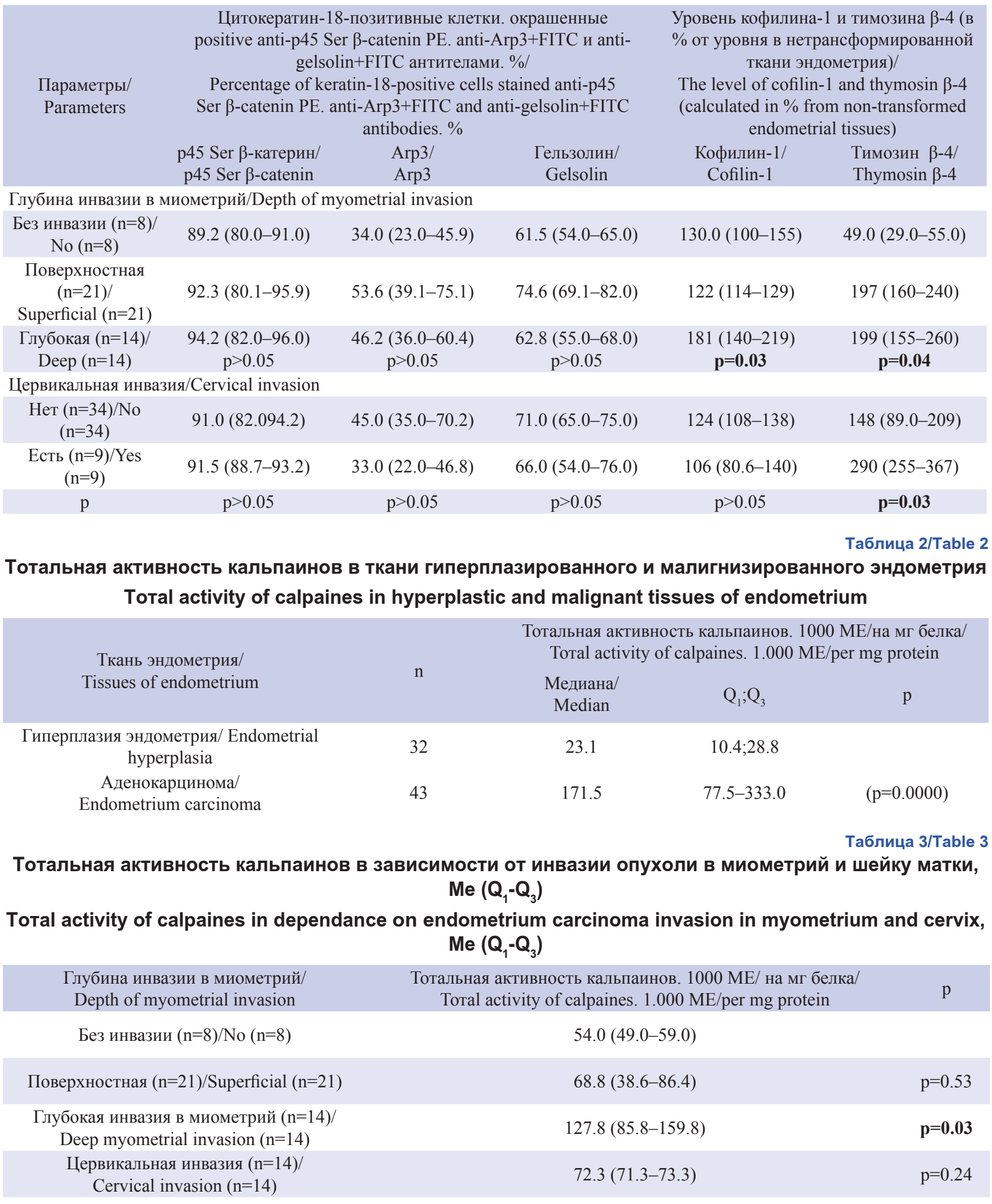




\section{Однофакторный анализ для предсказания перехода гиперплазии эндометрия в карциному} эндометрия

\section{Univariate analysis to predict the transition of endometrial hyperplasia to endometrium carcinoma}

\begin{tabular}{|c|c|c|c|}
\hline \multirow[b]{2}{*}{ Параметры/ Parameters } & \multicolumn{3}{|c|}{ Однофакторный анализ/Univariate analysis } \\
\hline & $\begin{array}{c}\text { Отношение шансов/ } \\
\text { Oddsratio }\end{array}$ & $95 \% \mathrm{CI}$ & $P$ value \\
\hline \multicolumn{4}{|c|}{ Уровень p45 Ser $\beta$-катенина/Level of p45 Ser $\beta$-catenin } \\
\hline $\begin{array}{l}\leq 89.5(\mathrm{n}=34) \\
>89.5(\mathrm{n}=29)\end{array}$ & 1.3 & $0.6-2.9$ & 0.506 \\
\hline \multicolumn{4}{|c|}{ Активность кальпаинов/Calpain activity } \\
\hline $\begin{array}{l}\leq 65.2(n=29) \\
>65.2(n=34)\end{array}$ & 6.1 & $1.5-24.9$ & 0.002 \\
\hline \multicolumn{4}{|c|}{ Уровень тимозина $\beta-4 /$ Level of thymosin $\beta-4$} \\
\hline $\begin{array}{l}\leq 82.5(\mathrm{n}=34) \\
>82.5(\mathrm{n}=29)\end{array}$ & 2.8 & $1.2-6.6$ & 0.015 \\
\hline \multicolumn{4}{|c|}{ Уровень кофилина-1/Level of cofilin-1 } \\
\hline $\begin{array}{l}\leq 105(n=38) \\
>105(n=39)\end{array}$ & 7.8 & $2.0-30.6$ & $<\mathbf{0 . 0 0 1}$ \\
\hline \multicolumn{4}{|l|}{ Уровень Arp3/Level of Arp3 } \\
\hline $\begin{array}{l}\leq 45(\mathrm{n}=38) \\
>45(\mathrm{n}=39)\end{array}$ & 0.3 & $0.1-1.3$ & 0.075 \\
\hline \multicolumn{4}{|c|}{ Уровень гельзолина/Level of gelsolin } \\
\hline $\begin{array}{l}\leq 67.5(n=36) \\
>67.5(n=44)\end{array}$ & 0.5 & $0.1-2.0$ & 0.301 \\
\hline
\end{tabular}

nontransformed cells. In EC there was no statistical correlation between calpain activity and motility protein levels. It should be noted that earlier we showed the association of the activity of intracellular proteases proteasomes with growth and transcription factors in the tissue of EC [34]. Probably in EC regulatory links concerning calpains are disrupted in comparison to non-transformed tissues.

To study promising future of motility associated proteins as predictor biomarkers in human EC the logistic regression analysis was performed. Regression analysis result is shown in Table 4 . The univariate analysis showed that the levels of thymosin $\beta-4$ and cofilin, as well as activity of calpains in endometrial hyperplasia tissues were independent predictors for cancer development. Calpain activity and level of cofilin-1 in hyperplasia tissue were more significant predictors then level of thymosin $\beta-4$.

ЛИТЕРАТУРA/REFERENCES

1. Siegel R.L., Miller K.D., Jemal A. Cancer statistics, 2018. CA Cancer J Clin. 2018 Jan; 68(1): 7-30. doi: 10.3322/caac.21442.

2. Felix A.S., Yang H.P., Bell D.W. Sherman M.E. Epidemiology of Endometrial Carcinoma: Etiologic Importance of Hormonal and Metabolic Influences. Adv Exp Med Biol. 2017; 943: 3-46. doi: 10.1007/978-3-31943139-0 1.

3. Kamal A., Tempest N., Parkes C., Alnafakh R., Makrydima S., Adishesh M., Hapangama D.K. Hormones and endometrial carcinogenesis. Horm Mol Biol Clin Investig. 2016 Feb; 25(2): 129-48. doi: 10.1515/ hmbci-2016-0005.

4. Spirina L.V., Bochkareva N.V., Kondakova I.V., Kolomiets L.A., Shashova E.E., Koval'V.D., Chernysheva A.L., Asadchikova O.N. Regulation of insulin-like growth factors and NF-kappaB by proteasome system in endometrial cancer. Mol Biol (Mosk). 2012 May-Jun; 46(3): 452-60.

\section{Conclusion}

Our investigation showed the decreased levels of cofilin-1, thymosin $\beta-4$ and increased expression of Arp3 in endometrial hyperplasia in comparison with EC that probably was necessary for cytoskeleton remodeling. Cofilin- 1 and thymosin $\beta-4$ expressions were associated with the depth of myometrial and cervical invasion in EC. We can assume that actin cytoskeleton reorganization in EC invasive cell may be performed through regulation of cofilin-1 and thymosin $\beta-4$. Received associations between levels of ABPs and total calpain activity allow us to suppose the involvement of these proteases in the regulation of cell migration and invasion in endometrial hyperplasia. Levels of thymosin $\beta-4$, cofilin and total calpain activity are independent cancer risk factors in patients with endometrial hyperplasia and may be considered as predictive biomarkers for prognosis of hyperplasia transition to cancer.

5. Gawron I., Łoboda M., Babczyk D., Ludwin I., Basta P., Pityński K., Ludwin A. Endometrial cancer and hyperplasia rate in women before menopause with abnormal uterine bleeding undergoing endometrial sampling. Przegl Lek. 2017; 74(4): 139-43.

6. Chen M., Jin Y., Li Y., Bi Y., Shan Y., Pan L. Oncologic and reproductive outcomes after fertility-sparing management with oral progestin for women with complex endometrial hyperplasia and endometrial cancer. Int J Gynaecol Obstet. 2016 Jan; 132(1): 34-8. doi: 10.1016/j. ijgo.2015.06.046.

7. Markowska A., Pawałowska M., Lubin J., Markowska J. Signalling pathways in endometrial cancer. Contemp Oncol (Pozn). 2014; 18(3): 143-8. doi: 10.5114/wo.2014.43154.

8. Zhang X.H., Li M., Kang Y.J., Xie Y.Q., Cao Y.X. Long non-coding RNA LINP1 functions as an oncogene in endometrial cancer progression by regulating the PI3K/AKT signaling pathway. Eur Rev Med Pharmacol Sci. 2019 Aug; 23(16): 6830-6838. doi: 10.26355/eurrev_201908_18722. 
9. Kondakova I.V., Spirina L.V., Shashova E.E., Koval' V.D., Kolomiets L.A., Chernysheva A.L., Slonimskaia E.M. Proteasome activity in tumors of female reproductive system. Bioorg Khim. 2012 Jan-Feb; 38(1): 106-10. doi: 10.1134/s106816201201013x.

10. Kondakova I.V., Spirina L.V., Koval V.D., Shashova E.E., Choinzonov E.L., Ivanova E.V., Kolomiets L.A., Chernyshova A.L., Slonimskaya E.M., Usynin E.A., Afanas'ev S.G. Chymotrypsin-like activity and subunit composition of proteasomes in human cancers. Molecular Biology. 2014; 48(3): 384-389. doi: 10.1134/S002689331403011X.

11. Nesina I.P., Iurchenko N.P., Buchynska L.G. Markers of the epithelial-mesenchymal transition in cells of endometrial carcinoma. Exp Oncol. 2018 Oct; 40(3): 218-222.

12. dos Remedios C.G., Chhabra D., Kekic M., Dedova I.V., Tsubakihara M., Berry D.A., Nosworthy N.J. Actin binding proteins: regulation of cytoskeletal microfilaments. Physiol Rev. 2003 Apr; 83(2): 433-73. doi: 10.1152/physrev.00026.2002.

13. Huang H.C., Hu C.H., Tang M.C., Wang W.S., Chen P.M., Su Y. Thymosin beta4 triggers an epithelial-mesenchymal transition in colorectal carcinoma by upregulating integrin-linked kinase. Oncogene. $2007 \mathrm{Apr}$ 26; 26(19): 2781-90. doi: 10.1038/sj.onc.1210078.

14. Maimaiti Y., Tan J., Liu Z., Guo Y., Yan Y., Nie X., Huang B. Zhou J., Huang T. Overexpression of cofilin correlates with poor survival in breast cancer: A tissue microarray analysis. Oncol Lett. 2017 Aug; 14(2): 2288-2294. doi: 10.3892/ol.2017.6413.

15. Baczynska D., Bombik I., Malicka-Błaszkiewicz M. $\beta$-Catenin Expression Regulates Cell Migration of Human Colonic Adenocarcinoma Cells Through Gelsolin. Anticancer Res. 2016; 36(10): 5249-56. doi: 10.21873/anticanres.11095.

16. Kazazian K., Go C., Wu H., Brashavitskaya O., Xu R., Dennis J.W., Gingras A.C., Swallow C.J. Plk4 Promotes Cancer Invasion and Metastasis through Arp2/3 Complex Regulation of the Actin Cytoskeleton. Cancer Res. 2017 Jan 15; 77(2): 434-447. doi: 10.1158/0008-5472.CAN-162060 .

17. Bowser J.L., Blackburn M.R., Shipley G.L., Molina J.G., Dunner K.Jr., Broaddus R.R. Loss of CD73-mediated actin polymerization promotes endometrial tumor progression. J Clin Invest. 2016 Jan; 126(1): 220-38. doi: 10.1172/JCI79380.

18. Kiewisz J., Wasniewski T., Kmiec Z. Participation of WNT and $\beta$-Catenin in Physiological and Pathological Endometrial Changes: Association with Angiogenesis. Biomed Res Int. 2015; 2015: 854056. doi: 10.1155/2015/854056.

19. Chan D.W., Mak C.S., Leung T.H., Chan K.K., Ngan H.Y. Downregulation of Sox 7 is associated with aberrant activation of Wnt/b-catenin signaling in endometrial cancer. Oncotarget. 2012 Dec; 3(12): 1546-56. doi: 10.18632/oncotarget.667.

20. Wang E.,Wang D., Li B., Ma H.,Wang C., Guan L., Zhang $H$., Yi L., Li S. Capn4 promotes epithelial-mesenchymal transition in human melanoma cells through activation of the $\mathrm{Wnt} / \mathrm{\beta}$-catenin pathway. Oncol Rep. 2017 Jan; 37(1): 379-387. doi: 10.3892/or.2016.5247.

21. Bravo-Cordero J.J., Cordani M., Soriano S.F., Díez B., Muñoz-Agudo C., Casanova-Acebes M., Boullosa C., Guadamillas M.C., Ezkurdia I., González-Pisano D., Del Pozo M.A., Montoya M.C. A novel high-content analysis tool reveals Rab8-driven cytoskeletal reorganization through Rho GTPases, calpain and MT1-MMP. J Cell Sci. 2016 Apr 15; 129(8): 1734 49. doi: $10.1242 /$ jcs. 174920.

22. Хи C., Yu X., Zhu Y., Cai Z., Yu L., Lin Y., Yu H., Xue Z., Zhou L. Overexpression of calpain-1 predicts poor outcome in patients with colorectal cancer and promotes tumor cell progression associated with downregulation of FLNA. Oncol Rep. 2019 Jun; 41(6): 3424-3434. doi: 10.3892/or.2019.7121.

23. Ivanova E.V., Kondakova I.V., Spirina L.V., Afanas'ev S.G., Avgustinovich A.V., Cheremisina O.V. Chymotrypsin-like activity of proteasomes and total calpain activity in gastric and colorectal cancer. Bull Exp Biol Med. 2014 Oct; 157(6): 781-4. doi: 10.1007/s10517-014-2666-y.

24. Kondakova I.V., Iunusova N.V., Spirina L.V., Kolomiets L.A., Villert A.B. Association of intracellular proteinase activities with the content of locomotor proteins in tissues of primary tumors and metastasis in ovarian cancer. Bioorg Khim. 2014 Nov-Dec; 40(6): 735-42. doi: 10.1134/ s1068162014060089.

25. Salehin D., Fromberg I., Haugk C., Dohmen B., Georg T., Bohle R.M., Bauerschlag D., Maass N., Friedrich M. Immunhistochemical analysis for expression of calpain 1, calpain 2 and calpastatin in endometrial cancer. Anticancer Res. 2010 Jul; 30(7): 2837-43.

26. Sandmann S., Prenzel F., Shaw L., Schauer R., Unger T. Activity profile of calpains I and II in chronically infarcted rat myocardium-influence of the calpain inhibitor CAL 9961. Br J Pharmacol. 2002 Apr; 135(8): 1951-8. doi: 10.1038/sj.bjp.0704661.

27. Zhou J., Wang Y., Fei J., Zhang W. Expression of cofilin 1 is positively correlated with the differentiation of human epithelial ovarian cancer. Oncol Lett. 2012 Dec; 4(6): 1187-1190. doi: 10.3892/ol.2012.897.

28. Gun B.D., Bahadir B., Bektas S., Barut F., Yurdakan G., Kandemir N.O., Ozdamar S.O. Clinicopathological significance of fascin and CD44v6 expression in endometrioid carcinoma. Diagn Pathol. 2012 Jul 11; 7: 80. doi: 10.1186/1746-1596-7-80.

29. Nishimura S., Tsuda H., Kataoka F., Arao T., Nomura H., Chiyoda T., Susumu N., Nishio K., Aoki D. Overexpression of cofilin 1 can predict progression-free survival in patients with epithelial ovarian cancer receiving standard therapy. Hum Pathol. 2011 Apr; 42(4): 2012-21. doi: 10.1016/j.humpath.2010.07.019.

30. Ji P., Diederichs S., Wang W., Böing S., Metzger R., Schneider P.M., Tidow N., Brandt B., Buerger H., Bulk E., Thomas M., Berdel W.E., Serve H., Müller-Tidow C. MALAT-1, a novel noncoding RNA, and thymosin beta4 predict metastasis and survival in early-stage non-small cell lung cancer. Oncogene. 2003 Sep 11; 22(39): 8031-41. doi: 10.1038/ sj.onc. 1206928 .

31. Noske A., Denkert C., Schober H., Sers C., Zhumabayeva B., Weichert W. Dietel M., Wiechen K. Loss of Gelsolin expression in human ovarian carcinomas. Eur J Cancer. 2005; 41(3): 461-9. doi: 10.1016/j. ejca.2004.10.025.

32. Zheng H.C., Zheng Y.S., Li X.H., Takahashi H., Hara T., Masuda S. Yang X.H., Guan Y.F., Takano Y. Arp2/3 overexpression contributed to pathogenesis, growth and invasion of gastric carcinoma. Anticancer Res. 2008 Jul-Aug; 28(4B): 2225-32.

33. Yoon Y.J., Han Y.M., Choi J., Lee Y.J., Yun J., Lee S.K., Lee C.W., Kang J.S., Chi S.W., Moon J.H., Lee S., Han D.C., Kwon B.M. Benproperine, an ARPC2 inhibitor, suppresses cancer cell migration and tumor metastasis. Biochem Pharmacol. 2019 May; 163: 46-59. doi: 10.1016/j. bcp.2019.01.017

34. Spirina L.V., Yunusova N.V., Kondakova I.V., Kolomiets L.A., Koval V.D., Chernyshova A.L., Shpileva O.V. Association of growth factors, HIF-1 and NF- $\kappa$ B expression with proteasomes in endometrial cancer. Mol Biol Rep. 2012 Sep; 39(9): 8655-62. doi: 10.1007/s11033-012-1720-y.

Поступила/Received 10.12.2019

Принята в печать/Accepted 12.02.2020

\section{СВЕДЕНИЯ ОБ АВТОРАХ}

Юнусова Наталья Валериевна, доктор медицинских наук, ведущий научный сотрудник, Научно-исследовательский институт онкологии, Томский национальный исследовательский медицинский центр Российской академии наук (г. Томск, Россия). SPINкод: 3513-1888. Researcher ID (WOS): C-9275-2012. Author ID (Scopus): 8354141400. ORCID: 0000-0003-4595-417.

Спирина Людмила Викторовна, доктор медицинских наук, ведущий научный сотрудник, Научно-исследовательский институт онкологии, Томский национальный исследовательский медицинский центр Российской академии наук (г. Томск, Россия). SPINкод: 1336-8363. Researcher ID (WOS): A-7760-2012. Author ID (Scopus): 36960462500. ORCID: 0000-0002-5269-736X.

Чернышова Алена Леонидовна, доктор медицинских наук, ведущий научный сотрудник, Научно-исследовательский институт онкологии, Томский национальный исследовательский медицинский центр Российской академии наук (г. Томск, Россия). SPINкод: 2522-7513. Researcher ID (WOS): C-8608-2012. Author ID (Scopus): 55220758100. ORCID: 0000-0002-8194-281.

Колегова Елена Сергеевна, кандидат медицинских наук, научный сотрудник, Научно-исследовательский институт онкологии, Томский национальный исследовательский медицинский центр Российской академии наук (г. Томск, Россия). SPIN-код: 58651264. Researcher ID (WOS): L-8669-2016. Author ID (Scopus): 57190575464. ORCID: 0000-0001-9122-3274.

Сиденко Евгения Александровна, аспирант, Научно-исследовательский институт онкологии, Томский национальный исследовательский медицинский центр Российской академии наук (г. Томск, Россия). SPIN-код: 3736-0140. ORCID: 0000-00015838-9459. 
Коломиец Лариса Александровна, доктор медицинских наук, профессор, заведующая отделением онкогинекологии, Научноисследовательский институт онкологии, Томский национальный исследовательский медицинский центр Российской академии наук (г. Томск, Россия). SPIN-код: 6316-1146. Researcher ID (WOS): C-8573-2012. Author ID (Scopus): 7004921120. ORCID: 0000-0002-6854-8940.

Кондакова Ирина Викторовна, доктор медицинских наук, профессор, заведующая лабораторией биохимии опухолей, Научно-исследовательский институт онкологии, Томский национальный исследовательский медицинский центр Российской академии наук (г. Томск, Россия). SPIN-код: 9338-4149. Researcher ID (WOS): C-8658-2012. Author ID (Scopus): 6701872510. ORCID: 0000-0002-0947-8778.

\section{ВКЛАД АВТОРОВ}

Юнусова Наталья Валериевна: анализ материала, составление черновика рукописи.

Спирина Людмила Викторовна: анализ материала.

Чернышова Алена Леонидовна: набор клинического материала.

Колегова Елена Сергеевна: статистическая обработка материала.

Сиденко Евгения Александровна: составление базы данных.

Коломиец Лариса Александровна: критический пересмотр с внесением ценного интеллектуального содержания.

Кондакова Ирина Викторовна: разработка концепции научной работы, анализ научной работы.

\section{Финансирование}

Это исследование не потребовало дополнительного финансирования.

Конфликт интересов

Авторы объявляют, что у них нет конфликта интересов.

\section{ABOUT THE AUTHORS}

Natalia V. Yunusova, DSc, Leading Researcher, Laboratory of Tumor Biochemistry, Cancer Research Institute, Tomsk National Research Medical Center, Russian Academy of Sciences (Tomsk, Russia). Author ID (Scopus): 845414400. Researcher ID (WOS): C-9275-2012. ORCID: 0000-0003-4595-4177.

Lyudmila V. Spirina, DSc, Senior Researcher, Laboratory of Tumor Biochemistry, Cancer Research Institute, Tomsk National Research Medical Center, Russian Academy of Sciences (Tomsk, Russia). Researcher ID (WOS): A-7760-2012. Author ID (Scopus): 36960462500 .

Alena L. Chernyshova, MD, DSc, Leading Researcher, Department of Gynecology, Cancer Research Institute, Tomsk National Research Medical Center, Russian Academy of Sciences (Tomsk, Russia). Author ID (Scopus): 55220758100. Reseacher ID (WOS): C-8608-2012. ORCID: 0000-0002-8194-2811.

Elena S. Kolegova, PhD, Researcher, Cancer Research Institute, Tomsk National Research Medical Center, Russian Academy of Sciences (Tomsk, Russia). Researcher ID (WOS): L-8669-2016. Author ID (Scopus): 57190575464. ORCID: 0000-0001-9122-3274.

Yevgeniya A. Sidenko, Postgraduate, Cancer Research Institute, Tomsk National Research Medical Center, Russian Academy of Sciences (Tomsk, Russia). ORCID: 0000-0001-5838-9459.

Larisa A. Kolomiets, MD, DSc, Professor, Head of Gynecology Department, Cancer Research Institute, Tomsk National Research Medical Center, Russian Academy of Sciences (Tomsk, Russia). Author ID (Scopus): 7004921120. Researcher ID (WOS): C-85732012. ORCID: 0000-0002-6854-8940.

Irina V. Kondakova, DSc, Professor, Head of the Laboratory of Tumor Biochemistry, Cancer Research Institute, Tomsk National Research Medical Center, Russian Academy of Sciences (Tomsk, Russia). Researcher ID (WOS): C-8658-2012. Author ID (Scopus): 6701872510. ORCID: 0000-0002-0947-8778.

\section{AUHTOR CONTRIBUTION}

Natalia V. Yunusova: data analysis, drafting of the manuscript.

Lyudmila V. Spirina: data analysis.

Alena L. Chernyshova: data collection.

Elena S. Kolegova: statistical analysis.

Yevgeniya A. Sidenko: compilation database.

Larisa A. Kolomiets: critical revision for the important intellectual content.

Irina V. Kondakova: study conception, analysis of the study results.

\section{Funding}

This study required no funding.

Conflict of interest

The authors declare that they have no conflict of interest. 